\author{
MaPan : Jurnal Matematika dan Pembelajaran \\ p-ISSN: 2354-6883 ; e-ISSN: 2581-172X \\ Volume 8, No 1, June 2020 (140-152) \\ DOI: https://doi.org/10.24252/mapan.2018v8n1a11
}

\title{
INTERPERSONAL COMMUNICATION BETWEEN LECTURERS AND STUDENTS IN INFLUENCING STUDENT'S LEARNING MOTIVATION
}

\author{
Munawarah'), Rina Novianty2) \\ 1,2State Islamic Institute of Bone \\ 1,2Jl. Hos Cokroaminoto No.1, Macanang, Tanete Riattang Bar, Kabupaten Bone \\ E-mail: munawarahr@gmail.com ${ }^{1}$, rinanovianty87@gmail.com²)
}

Received May 06, 2020; Revised June 24, 2020; Accepted June 27, 2020

\begin{abstract}
:
This study is an ex post facto that aimed to determine the effect of interpersonal communication between lecturers and students on the students' learning motivation. The population included all 4th-semester students at the Department of Sharia and Islamic Economics of State Institute Islamic Institute of Bone, consisting of 210 students with the sample as many as 42 students. The methods of data collection were observation, questionnaires, and documentation. The techniques of data analysis used were descriptive analysis and inferential analysis using a simple linear regression test. Based on the calculation of the questionnaire score, it was known that the significance value obtained at 0.00 was stated to be smaller than the confidence level of $0.05(0.00$ $<0.05)$. Based on the significance value, it can be concluded that $\mathrm{H}_{0}$ was rejected, which means that there was an effect of Interpersonal Communication on the students' learning motivation. While the R-squared value $=0.650$, which means that the effect of interpersonal communication between the lecturers and students to the students' learning motivation was $65 \%$ while $35 \%$ of students' learning motivation was affected by other variables that are not the focus of this study. The results of this study proved that interpersonal communication between lecturers and students consisting of several indicators, namely the attitude of openness, empathy, support, positive attitude, and equality, has a positive effect on the students' learning motivation.
\end{abstract}

Keywords: Interpersonal Communication, Learning Motivation

\section{KOMUNIKASI INTERPERSONAL ANTARA DOSEN DAN MAHASISWA DALAM MEMPENGARUHI MOTIVASI BELAJAR MAHASISWA}

\begin{abstract}
Abstrak:
Penelitian ini merupakan penelitian ex post facto, bertujuan untuk mengetahui pengaruh komunikasi interpersonal dosen dan mahasiwa terhadap motivasi belajar mahasiswa. Populasi dalam penelitian ini adalah seluruh mahasiswa semester 4 Jurusan Syariah dan Ekonomi Islam IAIN Bone yang berjumlah 210 mahasiswa dengan sampel sebanyak 42 mahasiswa. Pengambilan data menggunakan metode observasi, angket, dan dokumentasi. Teknik analisis data menggunakan analisis deskriptif dan analisis inferensial menggunakan uji regresi linear sederhana. Berdasarkan perhitungan skor angket diketahui bahwa nilai signifikansi yang diperoleh sebesar 0,00 dinyatakan lebih kecil dari taraf kepercayaan 0,05 $(0,00<0,05)$. Berdasarkan nilai
\end{abstract}


signifikansi dapat disimpulkan bahwa $\mathrm{H}_{0}$ ditolak, yang berarti bahwa ada pengaruh komunikasi interpersonal terhadap motivasi belajar mahasiswa. Sementara itu, nilai $\mathrm{R}$ Square $=0.650$ yang berarti bahwa pengaruh komunikasi interpersonal antara dosen dan mahasiswa terhadap motivasi belajar mahasiswa sebesar $65 \%$ sedangkan $35 \%$ motivasi belajar mahasiswa dipengaruhi oleh variabel lain yang tidak menjadi fokus pada penelitian ini. Hasil penelitian ini membuktikan bahwa komunikasi interpersonal antara dosen dan mahasiswa yang terdiri dari beberapa indikator yakni adanya sikap keterbukaan, empati, dukungan, sikap positif, dan kesamaan/kesetaraan berpengaruh positif terhadap motivasi belajar mahasiswa.

Kata kunci: Komunikasi Interpersonal, Motivasi Belajar

How to Cite: Munawarah \& Novianty, R. (2020). Interpersonal Communication Between Lecturers and Students in Influencing Student's Learning Motivation. MaPan: Jurnal Matematika dan Pembelajaran, 8(1), 140-152. https://doi.org/10.24252/mapan.2018v8n1a11.

\section{INTRODUCTION}

7 ducation plays a very important role in realizing the nation's development. With education, there will be born human beings who can contribute to the country with their talents and potential. Education and teaching consist of interactions between educators and students who use almost all the language media, both spoken, written, and motion and sign language. The interaction that uses language media is called communication. Thus, communication plays a decisive role in the interaction of education or teaching (Indonesian Law Number 14 Year 2005). The learning activities are communication activities. In the Dictionary of Psychology, the Dictionary of Behavioral Science, communication is the transmission of energy changes from another place such as in a system of conditions or the delivery of sound waves (Riswandi, 2013). Mulyana (2016) stated that the definition of communication according to the expert included, (a) William I. Gorden, communication is a dynamic transaction involving ideas and feelings, (b) Judy C. Pearson and Paul E. Nelson, communication is the process of understanding and sharing meaning, (c) Stewart L. T Tubbs and Sylvia Moss, communication is the process of forming meaning between two or more people. Accordingly, communication can be interpreted as a process of interaction that is characterized by the existence of actions, changes, exchanges, and movements between the communicators and communicants in the delivery of information or messages.

In establishing interactions with others, communication is said to be effective if it is characterized by good interpersonal relationships (Hasanah, 
2015). The communication referred to in this study is Interpersonal communication. The opinion of DeVito (2013) on interpersonal communication is the process of sending and receiving messages between two individuals or in a small group of people with some immediate effect and feedback. Through interpersonal communication, the communication between educators and students can express what it is felt and can receive statements between the two components so that it can cause a sense of caring and understanding. Interpersonal communication is preceded by interpersonal attraction. Interpersonal attraction is an interest that occurs between participants in interpersonal communication. The more interested we are in someone, the greater our tendency to communicate. This fondness for others, positive attitude, and attractiveness of a person are called interpersonal attraction (Riswandi, 2013: 65). Almost every Expert interprets the term interpersonal communication according to their perspectives. According to Dean Barnlund in Harapan \& Ahmad (2014), interpersonal communication was described as people's behavior at face-to-face meetings in informal social situations and conduct focused interactions through exchanging verbal and non-verbal cues that are reciprocated. Furthermore, Arni (2010) defined interpersonal communication as the process of exchanging information between a person with at least one person or usually between two people who can be directly identified. Based on these opinions, it can be concluded that interpersonal communication in this study is a process of sending and receiving messages between two people or a small group of people in a friendly atmosphere with various forms of effects and also feedback, which is done for goal and various reasons, to solve a problem or just exchange information with others.

Rakhmat (2012) said that interpersonal communication was very important for one's life. One important role of interpersonal communication is explained by Johson in Supratiknya (1995), who said that interpersonal communication helped the intellectual and social development of every human being. Interpersonal communication can occur between the children and their parents, between the lecturers and students, and so on. Communication between lecturers and students can take place both in the classroom and outside the classroom (Abubakar, 2015). The communication process that runs smoothly between the lecturers or teachers and students will bring good learning outcomes. Conversely, communication can be obstructed because lecturers or teachers do not give communication spaces. They are less able to explore the ability of students to ask, so the students will be afraid to ask questions, and 
some other reasons will make the learning outcomes not optimal. The primary key to communication in the classroom lies in the lecturers or teachers (Naim, 2011: 53). According to Riswandi (2013: 67), there were five stages in interpersonal communication, namely (a) contact, (b) involvement, (c) intimacy, (d) destruction, and (e) termination. To start, develop, and maintain close, warm, and productive communication with others, teachers or lecturers, or whoever needs several basic communication skills. While, according to DeVito (2013), effective interpersonal communication is openness, empathy, supportiveness, positiveness, and equality. Based on the description above, the researcher concludes that the indicators of interpersonal communication in this study consist of openness, empathy, support, positive attitude, and equality. The selection of indicators is taken from DeVito's theory, which is easy to describe and easy to understand.

According to Arni (2010: 165), there were several goals of interpersonal communication, including (a) finding oneself, (b) discovering the outside world, (c) forming and maintaining. Based on some of these explanations, Dispini \& Romadoni (2016) say that active communication is expected to reduce the misunderstanding between students and lecturers in learning mathematics. However, in reality, there are still many deficiencies done by the lecturers in interacting with students. One of them is explained by Mutawakkil \& Nuraedah (2019) in their research, which said that the less optimal lecturers' communication style, the students would not be motivated to learn. In line with this opinion, Haqi (2015) also said that communication in teaching and classroom management was not optimal, especially in terms of interacting with students in the classroom. Simanjuntak (2018), in his research, also considered that there were still many students who had low motivation to learn because of the communication ability of lecturers.

Based on the observations made on students of State Institute of Islamic Studies Bone in the Department of Sharia and Islamic Economics that when viewed from the condition of the lecturer, the quality of learning and the lecturers' way of teaching in the classroom are included in the good category. However, several things regarding communication in teaching and class management have not been maximized, especially in terms of interacting with students in the classroom, such as one-way communication (active lecturers, while the students are passive). When students have difficulty in learning in the classroom, many students ignore this misunderstanding of the lessons continuously because they are afraid and reluctant. Besides, many lecturers also 
seem indifferent and let their students solve their problems themselves. The lack of lecturer attention to the existing problems can make the teaching and learning process in the classroom less effective and efficient so that students' learning motivation decreases, and the students who are passive in learning will fail in their lecturing.

Abubakar (2015) emphasized that the aspect of motivation was very important in the learning process in higher education because it will determine the intensity of learning effort and encourage students to carry out certain activities related to learning activities. Utomo, Probandari, \& Suryani, (2016) suspected that there was a tendency that students who were able to communicate interpersonal well, both with lecturers and with other students, tend to have good learning motivation, and vice versa. Therefore, effective interpersonal communication is needed between the lecturers and students. Interpersonal communication among students or between students and lecturers is thought to be a factor that will give contribution to the improvement of students' motivation (Utomo, Probandari, \& Suryani, 2016). Motivation has an important position in achieving learning goals because, with motivation, students will know the direction of learning (Emda, 2017).

According to Sardiman (2011: 73), learning motivation was the overall driving force in the form of psychological factors that has a special role in terms of growing passion, making the students' hearts feel happy and eager to learn. According to Mc. Donald in Kompri (2016: 229), Motivation was a change in energy in an individual characterized by the appearance of "feeling" and preceded by a response to goals. Based on this opinion, it can be concluded that the learning motivation in this study is an impulse that comes from within a person to achieve the learning objectives. Students who have high learning motivation will study hard, but others who have low learning motivation will be lazy to learn.

In the process of teaching and learning, the wrong conditions often occur, which cause unintended consequences for learning success. As lecturers or teachers' effort to prevent such mistakes, the principles of learning motivation must be known, including meaningfulness, open communication, novelty, and pleasant learning conditions (Sardiman, 2011). Uno (2011: 9) said, in general, there were several indicators or elements that support the learning motivation, among others, suggests that the motivation that exists in each person has indicators include (a) the ideal and desire to be successful, (b) the encouragement and needs in learning, (c) the hope and future goals, (d) there is 
an appreciation in learning, (e) there are exciting activities in learning, (f) there is a conducive learning environment. Based on this explanation, the learning motivation indicators in this study consisted of (a) persevering in facing the tasks given, (b) be persistent in facing difficulties, (c) prefer to work independently, (d) like new things that are more creative. The researcher took four indicators out of eight indicators based on the consideration of the number of indicators adjusted to the ability of the researcher and the time of research implementation. The selection of indicators was taken from Sardiman's theory, which is simplified by taking indicators that are easily elaborated, easily understood, and have the same meaning as indicators of other theory, namely the theory of Hamzah.

Based on the background described above, this study aims to find out the effect of Interpersonal Communication between Lecturers and Students on Student Learning Motivation in Descriptive Statistics of the Sharia Economics Study Program Department of Sharia and Islamic Economics IAIN BONE.

\section{RESEARCH METHOD}

This study is an ex post facto research that aimed to determine the effect of interpersonal communication between the lecturers and students on the students' motivation. The variables in this study are divided into two variables, namely the independent variable and the dependent variable. The variables in this study are interpersonal communication (X), with indicators (a) openness, (b) empathy, (c) support, (d) positive attitude, (e) equality. While the motivation $(\mathrm{Y})$, with indicators (a) persevering in facing the tasks given, (b) be persistent in facing difficulties, (c) prefer to work independently, (d) like new things that are more creative.The population in this study was all 4th-semester students at Department of Sharia and Islamic Economics of State Islamic Institute of Bone, consisting of 210 students. The determination of the sample, according to Arikunto (2013: 210), when the subject is less than 100 people, then it is better to take all in the study. Furthermore, if the subject is large in scope, it can be taken $10-15 \%, 20-25 \%$, or more. In this study, the subjects or respondents sampled were $20 \%$ of the population, as many as 42 students.

The technique of data collection was done through observation, questionnaires, and documentation. Meanwhile, it is known that the interpersonal communication instrument used is valid with a calculated value of $0.605>0.257$ ( $\mathrm{r}$ table) and reliability value of 0.949 , a motivational instrument is also declared valid with a calculated value of $0.567>0.257$ ( $\mathrm{r}$ table) and 
reliability value of 0.909 . The data analysis used in this study was descriptive and inferential. The descriptive analysis used to describe the state of interpersonal communication variables and students' learning motivation. The data about interpersonal communication and students' learning motivation in the form of a checklist using a Likert scale.

The scoring for interpersonal communication had a range of 13 to 65 . To determine the measurement results criteria, the researcher used based on the theoretical average and ideal standard deviations with the conversion of quantitative to qualitative data on a scale of five (Azwar, 2014: 149). Interpersonal communication questionnaire between the lecturers and students consisted of 13 items so that it can be determined the theoretical average $(\mathrm{MI})=$ $1 / 2(65+13)=39$ and standard deviation $(\mathrm{SI})=1 / 6(65-13)=8.67$. The results of categorizing interpersonal communication variables are presented in table 1.

Table 1. The Categorization of Interpersonal Communication Variable Scores between the Lecturers and Students

\begin{tabular}{ccc}
\hline Interval & Interval Skor KD & Criteria \\
\hline $\mathbf{M i}+\mathbf{1}, \mathbf{5 S i}<\mathbf{X} \leq \mathbf{M i}+\mathbf{3 S i}$ & $52<\mathrm{X} \leq 65$ & Extremely High \\
$\mathbf{M i}+\mathbf{0 , 5 S i}<\mathbf{X} \leq \mathbf{M i}+\mathbf{1}, \mathbf{5 S i}$ & $43.34<\mathrm{X} \leq 52$ & High \\
$\mathbf{M i}-\mathbf{0}, \mathbf{5 S i}<\mathbf{X} \leq \mathbf{M i}+\mathbf{0} \mathbf{5 S i}$ & $34.66<\mathrm{X} \leq 43.34$ & Medium \\
$\mathbf{M i}-\mathbf{1}, \mathbf{5 S i}<\mathbf{X} \leq \mathbf{M i}-\mathbf{0 , 5 S i}$ & $26<\mathrm{X} \leq 34.66$ & Low \\
$\mathbf{M i}-\mathbf{3 S i} \leq \mathbf{X} \leq \mathbf{M i}-\mathbf{1 , 5 S i}$ & $13 \leq \mathrm{X} \leq 26$ & Extremely Low \\
\hline
\end{tabular}

The students' learning motivation questionnaire consisted of 12 items, so it can be determined that the theoretical average $(\mathrm{MI})=1 / 2(60+12)=36$ and standard deviation $(\mathrm{SI})=1 / 6(60-12)=8$. The results of the categorizing learning motivation variable are presented in table 2.

Table 2. The Categorization Scores Variable in Students' Learning Motivation

\begin{tabular}{ccc}
\hline Interval & Interval Skor KD & Criteria \\
\hline $\mathbf{M i}+\mathbf{1}, \mathbf{5 S i}<\mathbf{X} \leq \mathbf{M i}+\mathbf{3 S i}$ & $48<\mathrm{X} \leq 60$ & Extremely High \\
$\mathbf{M i}+\mathbf{0 , 5 S i}<\mathbf{X} \leq \mathbf{M i}+\mathbf{1 , 5 S i}$ & $40<\mathrm{X} \leq 48$ & High \\
$\mathbf{M i}-\mathbf{0}, \mathbf{5 S i}<\mathbf{X} \leq \mathbf{M i}+\mathbf{0 , 5 S i}$ & $32<\mathrm{X} \leq 40$ & Medium \\
$\mathbf{M i}-\mathbf{1}, \mathbf{5 S} \mathbf{\mathbf { i }}<\mathbf{X} \leq \mathbf{M i}-\mathbf{0 , 5 S i}$ & $24<\mathrm{X} \leq 32$ & Low \\
$\mathbf{M i}-\mathbf{3 S i} \leq \mathbf{X} \leq \mathbf{M i}-\mathbf{1 , 5 S i}$ & $12 \leq \mathrm{X} \leq 24$ & Extremely Low \\
\hline
\end{tabular}

Furthermore, the inferential analysis was done to draw conclusions based on data that has been obtained during the research process. The inferential 
analysis used was a simple linear regression test. A simple linear regression test was used to determine the effect of communication between students and lecturers on the students' learning motivation.

\section{RESULTS AND DISCUSSION}

Referring to the theoretical basis and the research results obtained, this section discusses the results of the research as follows.

Table 3. The Description of Interpersonal Communication Variable and Students' Learning Motivation

\begin{tabular}{ccc}
\hline Descriptive & $\begin{array}{c}\text { Interpersonal } \\
\text { Communication }\end{array}$ & Motivation \\
\hline Average & 57.69 & 51.89 \\
Standard Deviation & 5.65022 & 4.50042 \\
The highest score obtained by the & 65 & 60 \\
students & 50 & 47 \\
The lowest score obtained by the students & 65 & 60 \\
Maximum possible score & 13 & 12 \\
\hline Minimum possible score & & \\
\hline
\end{tabular}

Based on table 3, it can be seen that the interpersonal communication score of students had an average of 57.69 , a standard deviation of 5.65022, the highest score obtained by students was 65 , the lowest score obtained by students was 50 , the maximum possible score was 65 , and the minimum possible value was 13 . While the average students' motivation was 51.89, the standard deviation was 4.50042 , the highest score obtained by students was 60 , the lowest score obtained by students was 47 , the maximum possible score was 60 , and the minimum possible score was 12 .

Table 4. The Frequency and Percentage of Each Category of Interpersonal Communication Scores and Students' Learning Motivation

\begin{tabular}{lcccc}
\hline \multirow{2}{*}{ Criteria } & \multicolumn{2}{c}{ Interpersonal Communication } & \multicolumn{2}{c}{ Motivation } \\
\cline { 2 - 5 } Extremely High & Frequency & $\%$ & Frequency & $\%$ \\
High & 40 & 95.24 & 41 & 97.62 \\
Medium & 2 & 4.76 & 1 & 2.38 \\
Low & 0 & 0 & 0 & 0 \\
Extremely Low & 0 & 0 & 0 & 0 \\
\hline
\end{tabular}


Based on table 4, it can be seen that interpersonal communication between students and lecturers was $95.24 \%$ of students who got interpersonal communication scores with extremely high criteria and $4.76 \%$ on high criteria. The students' learning motivation was $97.62 \%$ of students who got learning motivation scores with extremely high criteria, and $2.38 \%$ on high criteria.

A simple linear regression test was used to measure the extent of the effect of interpersonal communication on student learning motivation in the course Descriptive Statistics at the Department of Sharia and Islamic Economics of State Islamic Institute of Bone, and the results are presented in table 5.

Table 5. Interpersonal Communication Regression Model

\begin{tabular}{llccccc}
\hline Model & $\begin{array}{c}\text { Unstandar } \\
\text { dized } \\
\text { B }\end{array}$ & $\begin{array}{c}\text { Coefficients } \\
\text { Std. Error }\end{array}$ & $\begin{array}{c}\text { Standardized } \\
\text { Coefficients } \\
\text { Beta }\end{array}$ & t & Sig. \\
\hline $\mathbf{1}$ & (Constant) & 14.840 & 4.319 & & 3.436 & .001 \\
& $\begin{array}{l}\text { Komunikasi } \\
\text { _Interperso }\end{array}$ & .642 & .073 & .806 & 8.616 & .001 \\
& nal & & & & & \\
\hline
\end{tabular}

a. Dependent Variable: Motivasi_Belajar

Based on the table 5, it can be seen the regression model of interpersonal communication $(X)$ and learning motivation $(Y)$, where the equation of the regression line can be expressed as $Y=14.840+0.642 X$. The equation shows that the $X$ coefficient value of 0.642 , which means that if interpersonal communication $(X)$ increased by 1 point, the students' motivation $(Y)$ would be increased by 0.642 points. The $t_{\text {-count }}=0.806$ while $t_{\text {-table }}=0.680$. It means that the $\mathrm{t}_{\text {-count }}=0.806>\mathrm{t}_{\text {-table }}=0.680$. Meanwhile, the significance value obtained at 0.00 was stated to be smaller than the confidence level of $0.05(0.00<0.05)$. Based on the $t_{\text {-value }}$ and significance value, it can be concluded that $\mathrm{H}_{0}$ was rejected and $\mathrm{H}_{\mathrm{a}}$ was accepted. It means that there was an effect of interpersonal communication on the students' learning motivation in the Descriptive Statistics course at the Department of Sharia and Islamic Economics of State Islamic Institute of Bone.

Meanwhile, to measure the extent of the effect of interpersonal communication on the students' learning motivation, it can use the R-Squared value in table 6. 
Table 6. Summary Model

\begin{tabular}{ccccc}
\hline Model & $\mathbf{R}$ & $\begin{array}{c}\mathbf{R} \\
\text { Square }\end{array}$ & $\begin{array}{c}\text { Adjusted R } \\
\text { Square }\end{array}$ & $\begin{array}{c}\text { Std. Error of } \\
\text { the Estimate }\end{array}$ \\
\hline $\mathbf{1}$ & $.806^{\mathrm{a}}$ & .650 & .641 & 2.696 \\
\hline
\end{tabular}

a. Predictors: (Constants), Komunikasi_Interpersonal

Based on table 6, it is known that the R-Squared value $=0.650$. It means that the effect of interpersonal communication between lecturers and students on the students' learning motivation was $65 \%$, while $35 \%$ of students' learning motivation was affected by other variables that are not the focus of this study. Therefore, based on several results of calculations that have been made, it can be concluded that interpersonal communication between students and lecturers $(\mathrm{X})$ had a positive effect on the students' learning motivation $(\mathrm{Y})$ with a total effect of $65 \%$.

The results of this study proved that interpersonal communication between lecturers and students consisting of several indicators, namely the attitude of openness, empathy, support, positive attitude, and equality, has a positive effect on the students' learning motivation. This is in line with the opinion of Sardiman (2011) who said that educator as a motivator was very important in teaching-learning interactions because it involved the essence of the work of educating that requires social skills, concerning performance in terms of personalization and self-socialization. Surya (2003), also said the implementation of effective interpersonal communication consisted of openness and empathy, support and positive attitude, balance, confidence, freshness, interaction management, disclosure, orientation to others. Therefore, in realizing this, someone must have the ability to communicate, in this case, interpersonal communication.

Interpersonal communication is as a process of sending and receiving messages between two people or a small group of people in an atmosphere that is familiar with various forms of effects and also feedback, which is done because of purpose and various reasons, to solve a problem or just exchange information with other people. The lack of communication can obstruct the student development. Hence, the lecturers or teachers are required to have the ability to communicate effectively with students using the correct and good grammar. By communicating, it can meet the emotional needs, improve mental health, and learn the meaning of love, compassion, sympathy, respect, pride, even jealousy, and hatred. Effective lecturers or teachers do not only know the 
subject matter of the students but also can communicate the knowledge they have. The success in delivering the material depends on the smooth communication interaction between the lecturers or teachers and students. In achieving teaching and learning interactions, the clear communication between teachers or lecturers (communicator) with students (communicant) is needed.

In case interpersonal communication runs effectively, the information flow in the learning process will run smoothly. Then the students are motivated to follow the teaching and learning process. To increase students' motivation, the lecturer must maintain effective interpersonal communication (Abubakar, 2015). In line with this opinion, Zubaidi, Suryani, \& Probandari (2018) in their research also said that interpersonal communication between lecturers and students in the learning process was a very important factor in creating a pleasant learning atmosphere. Thus, it will create the students' learning motivation, and the lecturers will feel comfortable in teaching. The lecturers must be open, empathy, provides support, be positive, and equalize the students, so the students have high motivation in learning (Wahyudi, 2011). Merta (2019) said that lecturers Wira Bhakti Denpasar College and students had implemented interpersonal communication that includes openness, supportive behavior, positive behavior, empathy, and equality. The academic community has trusted each other, togetherness, warmth, and comfort in doing their respective assignments, so Wira Bhakti Denpasar College increasingly advanced.

Indeed, it is not easy to be an effective lecturer in the learning process. However, to achieve this, the lecturers need to communicate their knowledge well. Also, to achieve effective learning, smooth communication, the interaction between the lecturers and students needs to be done clearly. Teachers who understand the importance of this communication will be able to become qualified educators and create meaningful learning. For that reason, teachers should do that with an extra effort by doing positive communication involving verbal and nonverbal communication (Wahyuni, 2017). So, it can combine two activities that are efficient in achieving teaching and education goals. It means that teachers or lecturers must have the ability to communicate well since it is the main factor that affects the students' motivation in following the teaching and learning process. 


\section{CONCLUSION}

Based on the results and discussions of previous studies, it is known that interpersonal communication between students and lecturers is $95.24 \%$ of students who received interpersonal communication scores with very high criteria, and $4.76 \%$ on high criteria. In student motivation, it is obtained $97.62 \%$ of students who score learning motivation with very high criteria and $2.38 \%$ in high criteria. This means that there is an influence of interpersonal communication on student motivation in Descriptive Statistics course at the Department of Sharia and Islamic Economics of State Islamic Institute of Bone. The results of this study prove that interpersonal communication between lecturers and students consists of several indicators, namely openness, empathy, support, positive attitude, and equality, which have a positive influence on students' learning motivation.

\section{REFERENCES}

Abubakar, F. (2015). Pengaruh komunikasi interpersonal antara dosen dan mahasiswa terhadap motivasi belajar dan prestasi akademik mahasiswa. Jurnal Pekommas, 18(1), 53 - 62. https://doi.org/10.30818/jpkm. 2015. 1180106.

Arikunto, S. (2013). Metode penelitian pendidikan. Bandung: Alfabeta.

Arni, M. (2010). Komunikasi organisasi. Jakarta: Bumi Aksara.

Azwar. (2014). Penyusunan skala psikologi. Yogyakarta: Pustaka Pelajar.

DeVito, J., A. (2013). Interpersonal communication. New Jersey: Pearson Education Inc.

Dispini, M., \& Romadoni, A. N. (2016). Analisis penyebab keengganan mahasiswa dalam bertanya dan mengemukakan ide pada mata kuliah evaluasi pembelajaran. Prosiding Seminar Nasional Reforming Pedagogy. Yogyakarta: Universitas Sanata Dharma.

Emda, A. (2017). Kedudukan motivasi belajar siswa dalam pembelajaran. Lantanida Journal, 5(2), 93-196. https:/ / doi.org/10.22373/lj.v5i2.2838.

Haqi, L. (2015). Pengaruh komunikasi antara guru dengan siswa terhadap motivasi belajar siswa kelas V MI Matholi'ul Huda 02 Troso Jepara tahun pelajaran 2015. Thesis. Universitas Islam Negeri Walisongo Semarang). Retrieved from http://eprints.walisongo.ac.id/4596/.

Harapan, E., \& Ahmad, S. (2014). Komunikasi antar pribadi. Jakarta: PT. Raja Grafindo Persada.

Hasanah, H. (2015). Pengaruh Komunikasi interpersonal dalam menurunkan problem tekanan emosi berbasis gender. Sawwa: Jurnal Studi Gender, 11(1), 51-74. https:// doi.org/10.21580/sa.v11i1.1446.

Kompri. (2016). Motivasi pembelajaran perspektif guru dan siswa. Bandung: PT 
Remaja Rosdakarya Offside.

Merta, I., N. (2019). Interpersonal communication between Lecturers with students in Wira Bhakti Denpasar College. International Research Journal of Management, IT \& Social Sciences, Vol. 6 (1), 55-62. https://doi.org/ 10.21744/irjmis.v6n1.581.

Mulyana, D. (2016). Ilmu komunikasi. Bandung: PT Remaja Rosdakarya Offside. Mutawakkil, \& Nuraedah. (2019). Gaya komunikasi dosen dalam pembelajaran mahasiswa. Communicatus: Jurnal Ilmu Komunikasi, 3(2), 135-152. https:// doi.org/10.15575/cjik.v3i2.5765.

Naim, N. (2011). Dasar-dasar komunikasi pendidikan. Yogyakarta: Ar Ruzz Media. Rakhmat. (2012). Psikologi komunikasi. Bandung: PT Remaja Rosdakarya Offside. Republic of Indonesia. (2005). Law of the republic of indonesia number 14 year 2005 on teachers and lecturers. Jakarta, Indonesia: Ministry of Education.

Riswandi. (2013). Psikologi komunikasi. Jakarta: Graha Ilmu.

Sardiman. (2011). Interaksi dan motivasi belajar mengajar. Jakarta: PT. Raja Grafindo Persada.

Simanjuntak, B. (2018). Hubungan kemampuan berkomunikasi dosen dengan motivasi belajar mahasiswa Pendidikan Guru Sekolah Dasar (PGSD) FKIP Universitas Quality Medan. Jurnal Curere, 2(2), 194-202. https:// doi.org/10.36764/jc.v2i2.162.

Supratiknya, A. (1995). Komunikasi antar pribadi: Tinjauan psikologis. Yogyakarta: Kanisius.

Uno, H. B. (2011). Teori motivasi \& pengukurannya. Jakarta: Bumi Aksara.

Utomo, P. C., Probandari, A., \& Suryani, N. (2016). Hubungan komunikasi interpersonal mahasiswa dengan dosen dan antar mahasiswa dengan motivasi belajar. Jurnal Keterapian Fisik, 1(2), 90-94. https://doi.org/ 10.37341/jkf.v1i2.87.

Wahyudi, D. (2011). Efektivitas komunikasi interpersonal dosen pembimbing akademik dalam peningkatan motivasi belajar mahasiswa. Thesis. Universitas Bengkulu. Retrieved from http://repository.unib.ac.id/ $1809 /$.

Wahyuni, I. (2017). The power of verbal and nonverbal communication in learning. Advances in Social Science, Education and Humanities Research (ASSEHR), 125, 80-83. https:// doi.org/10.2991/icigr-17.2018.19.

Zubaidi, A. N., Suryani, N., \& Probandari, A. N. (2018). Hubungan antara komunikasi interpersonal dosen mahasiswa keaktifan berorganisasi dan aktualisasi diri dengan motivasi belajar di jurusan ortotik prostetik poltekkes surakarta. Jurnal Medika Respati, 13(1), 42-65. https: //doi.org/10.35842/mr.v13i1.238. 